\title{
Agricultural Self-sufficiency and Market Stability: A Revenue-neutral Approach to Wheat Sector in Egypt
}

\author{
Tetsuji Tanaka* \\ Department of Economics, Setsunan University, 17-8 Ikedanaka, Neyagawa, Osaka, 572-0074, Japan \\ *Corresponding author: tetsuji.tanaka@econ.setsunan.ac.jp
}

\begin{abstract}
Food self-sufficiency has become a high-priority policy agenda for developing governments in conjunction with the food price volatility in recent years. Even though a food autarky has been long regarded as one of the most potent strategies to achieve national food security, the effectiveness of the policy has not been investigated using a quantitative simulation model. In this paper, a stochastic global computable general equilibrium (CGE) model to analyze the benefits of a wheat self-sufficiency project in Egypt is constructed. The findings suggest that the policy alleviates the volatility of household welfare and the consumer price of wheat in Egypt, and substantially enhances the resilience of welfare against an export ban on wheat by Russia.
\end{abstract}

Keywords: food self-sufficiency, food policy, agricultural yield, export restriction

JEL Codes: C68, D24, Q17, F13

Cite This Article: Tetsuji Tanaka, "Agricultural Self-sufficiency and Market Stability: A Revenue-neutral Approach to Wheat Sector in Egypt.” Journal of Food Security, vol. 6, no. 1 (2018): 31-41. doi: 10.12691/jfs-6-1-4.

\section{Introduction}

Developing governments confront the dilemma of agricultural policy between fully open trade and closed borders for food security and cheaper foodstuffs. A number of nations including Egypt, Senegal, India, the Philippines, Qatar, Bolivia, and Russia aim to enhance domestic food production in the wake of the recent destabilized international food markets [1]. Critics, however, argue that a country bears a considerable cost in achieving high food self-sufficiency in return for the benefit from market steadiness. In contrast, a trade liberalization policy improves the efficiency of resource allocation but increases the risk exposure to the food supply by relying more on foreign sources. Tanaka and Hosoe [2] draw a policy implication that a country could stabilize food procurement by forming a diversified trade partners' network under a free trade regime. For these benefits, regional economic integration accelerated in the past decades, moving individual importers away from food autarky.

Egypt, the largest importer of wheat and a country where people rely on wheat products for around one-third of its food consumption in terms of calorie intake (FAOSTAT), may be one of the countries that were hurt most by the turbulence of global food markets in recent years. Homegrown wheat accounts for only half the wheat consumption in the nation, making the domestic markets susceptible to the volatility of foreign supply (FAOSTAT). Because of this, the government has attempted to raise its wheat self-sufficiency in order to insulate local markets from the vagaries of worldwide demand-supply shocks and has increased its efforts to scale up stockholding capacity of grain by building new silos. ${ }^{1}$

The fiscal deficit is a crucially important issue for the national government of Egypt, with cumulative debt reaching 92\% of the GDP in 2016 [3]. The total cost of the baladi bread program amounted to about EGP 11 billion (USD 1.815 billion) in 2011/2012, which was equivalent to about $1 \%$ of the GDP. The food subsidy program has been a mainstay in bolstering the social equity and political stability, reducing infant mortality and malnutrition since decades ago [4]. It has drained budgetary resources and has poorly targeted the poor, but has been reformed by omitting unqualified affluent families from the long list of beneficiaries. The authorities embarked on a drastic austerity reform, cutting not only food subsidy but energy subsidies as well. Under this circumstance, the reform is incompatible with the implementation of a wheat self-sufficiency policy that requires a sizable expenditure.

A food self-sufficiency policy has been long regarded as one of the most potent strategies in helping to solve food insecurity or stabilizing food supply, which, however, has not been fully analyzed particularly using a numerical model. Risk or security is a concept related to uncertainty, suggesting that a probabilistic model is needed to analyze a national security issue, but a probabilistic and quantitative assessment on how food self-sufficiency contributes to national food security is extremely scarce. ${ }^{2}$ Trade liberalization is indirectly linked with self-sufficiency, and

\footnotetext{
${ }^{1}$ Increasing silo capacity is an effective strategy for food security, but the definition of self-sufficiency in this article is production divided by consumption in Egypt, and I do not consider stock variations.

${ }^{2}$ As far as the author is concerned, there exists no literature on this issue with a simulation model.
} 
a slew of papers on agricultural free trade with a partial or general equilibrium model have been conducted in a deterministic manner (e.g. [5,6]), while few articles investigate agricultural free trade with a stochastic model [2].

This study evaluates the benefit of Egypt's wheat selfsufficiency policy achieved by raising the import tariff on wheat using a stochastic world-trade computable general equilibrium (CGE) model. More specifically, I shed light on the import tariff rate to achieve $100 \%$ self-sufficiency in wheat, to what extent the self-sufficiency policy contributes to the stability of household welfare and consumer price of wheat against the variability of wheat yield caused inside/outside Egypt, and the degree of welfare deterioration abatement in the nation against Russia's export restriction under the self-sufficiency regime. A revenue-neutral approach (the tariff revenue generated by the additional import tax is utilized for the subsidy of wheat production) is adopted in this analysis due to the fiscal issue.

\subsection{Literature Review}

The present paper discusses the relationship between food self-sufficiency and economic stability, which has been analyzed in many articles. ${ }^{3}$ Warr [7] analyzed the linkage between rice self-sufficiency rate and food security for Indonesia and argued that imposing import restrictions lifts the domestic price of rice hurting the most vulnerable people, most of whom are net consumers of rice, concluding that improving productivity is a more preferred policy choice since it reduces rice imports and boosts farmers' profits.

Risks associated with food supply in China were investigated by Bishwajit [8] who maintained that China would remain self-sufficient in rice and wheat, but is likely to continue to be reliant on other regions for soybeans and corn to feed the population. Food and nutritional situations in the country are likely to deteriorate due to various factors such as demographic pressures, climate change, environmental pollution, dwindling arable land, and depleting aquifers.

Bishwajit, et al. [9] took a closer look at self-sufficiency in rice and food security in South Asia. They argued that an increase in agricultural production is the most straightforward way to ameliorate food insecurity in agronomic states in South Asia, and that achievement of self-sufficiency will create surplus production, which allows rural people to generate income helping them move out of poverty. Despite that, these reasonings are useful for proposing food security policies, as they do not answer how robust South Asian countries can be against external shocks.

Clarete, et al. [10] identified the relationship between price volatility of rice, wheat, and maize and the tradability of those commodities (export divided by production) in the ASEAN regions, and found that rice had an inverse relationship while wheat and maize indicated positive relationships. Additionally, they maintained, with a Granger causality test, that extreme price volatility in rice tightened import and export restrictions backed by self-sufficiency programs rather than the other way around.

\footnotetext{
${ }^{3}$ For a comprehensive review, see Clapp (2017), which circumstantiated
} self-sufficiency and policy choice.
A quantitative assessment on agricultural trade liberalization for Japan was conducted by Tanaka and Hosoe [2]. This paper quantified the benefit of rice free trade and the risks associated with dependency on foreign supply using a stochastic CGE model that takes yield variability of global regions into account. One of the primal findings from their simulations is that households in Japan received huge gains by opening the domestic market mainly due to better efficiency of resource allocation and smoothing productivity shocks that happened in Japan but experienced limited loss from productivity shocks outside the country. This research contends that the self-sufficiency is lowered by the liberalization and people in Japan are likely to be more influenced by foreign shocks with abolishing trade barriers, but beneficial effects from trade surpass the negative impacts.

\section{Methodology}

Tanaka and Hosoe [2] extended the model constructed by Devarajan, et al. [11] on a global scale, introducing a stochastic concept using the Monte-Carlo method. I follow the extended model, but two major modifications are made for the purpose of this research. (1) In Tanaka and Hosoe [2], randomized productivity shocks were given following the independent and identically distributed normal distribution that suggests no correlation between regions was assumed. This implies that the model ignored the regional correlations of wheat productivity although they are observed in historical data. My model, on the other hand, considers the correlated relationships between countries when generating productivity shocks following the method of Ünal, et al. [12]. ${ }^{4}$ (2) An equation for the revenue neutrality between import tariff and producer subsidy is added to the model as follows:

$$
\left(1+t_{w}^{m}\right) p_{w}^{m} M_{w}=\left(1+s u b_{w}\right) p_{w}^{Z} Z_{w}
$$

where $t_{w}^{m}, p_{w}^{m}, M_{w}, s u b_{w}, p_{w}^{Z}$, and $Z_{w}$ are the import tax rate, import price, import, subsidy, producer price, and production, respectively. The data source of the model is the GTAP version 9 from which a multi-regional social accounting matrix is comprised of 13 regions, 10 sectors, and 5 production factors (Table 1).

Table 1. The aggregations of region, sector and factor in the model

\begin{tabular}{lll}
\hline Region & Sector & Factor \\
\hline Egypt & Paddy rice & Skilled labor \\
Russia & Wheat & Unskilled labor \\
USA & Other grains & Capital \\
France & Crops & Farmland \\
Ukraine & Meat \& livestocks & Natural resources \\
Kazakhstan & Processed foods & \\
Australia & Extraction & \\
Romania & Manufacturing & \\
Poland & Services & \\
EU & Transport & \\
MENA & & \\
Sub-Saharan Africa & & \\
Rest of the world & & \\
\hline
\end{tabular}

\footnotetext{
${ }^{4}$ See Table A1 for regional correlations estimated from historical data.
} 


\subsection{Yield Volatility}

The first step in constructing the stochastic model is to develop exogenous random productivity shocks for the wheat sector of each region. The Autoregressive Moving Average (ARMA) process is fit to time series yearly data on wheat yield from the FAOSTAT, which allows us to remove any time trends observed, and the residuals generated from the regressions are used to estimate productivity volatilities. The ARMA models are expressed as follows:

$$
Y_{t, r}=\sum_{i=t-p}^{t-1} \delta_{i, r} Y_{i, r}+\sum_{j=t-q}^{t} \theta_{j, r} \mu_{j, r},
$$

where $\delta_{i}$ and $\theta_{j}$ signify the parameters to be estimated, and $Y_{i}$ and $\mu_{j}$ are wheat yield and the prediction error in a given period of time, respectively [13]. The subscripts $p$, $q$, and $r$ express the number of autoregressive terms, the number of moving average terms, and the region, respectively. The Akaike information criterion (AIC) is used for model selection and the results and standard deviations of yield volatility are summarized in Table 2.

Table 2. ARMA results of wheat yield

\begin{tabular}{|c|c|c|c|c|c|c|}
\hline & \multicolumn{3}{|c|}{ Autoregressive factor } & \multicolumn{2}{|c|}{ Moving average factor } & \multirow[t]{2}{*}{ S.D. } \\
\hline & $\delta_{1}$ & $\delta_{2}$ & $\delta_{3}$ & $\theta_{1}$ & $\theta_{2}$ & \\
\hline Egypt & 1.93 & -1.08 & 0.11 & -3.28 & 2.28 & 0.049239 \\
\hline Russia & 0.80 & -0.08 & 0.16 & -0.42 & - & 0.121952 \\
\hline USA & 0.44 & -0.80 & 0.36 & 0.19 & 1.0 & 0.072185 \\
\hline France & -0.25 & -0.18 & - & - & - & 0.068156 \\
\hline Ukraine & 0.67 & 0.16 & - & -1.47 & - & 0.171147 \\
\hline Australia & 0.07 & 0.21 & -0.12 & - & - & 0.182489 \\
\hline Romania & -0.40 & 0.56 & 0.27 & -0.52 & -1.52 & 0.161482 \\
\hline Poland & 0.92 & -0.00 & - & -1.99 & - & 0.088696 \\
\hline EU & 0.25 & 0.64 & - & -0.91 & -1.22 & 0.074916 \\
\hline MENA & 0.70 & - & - & - & - & 0.077244 \\
\hline Sub-Saharan Afc. & 0.97 & 0.00 & - & - & - & 0.130832 \\
\hline Rest of the world & 0.14 & 0.30 & 0.30 & 1.20 & 0.39 & 0.039614 \\
\hline
\end{tabular}

Note: S.D. stands for the standard deviation.

Based on the standard deviations (SDs), 500 non-correlated randomized yield shocks are generated following $N\left(1, \sigma_{r}\right)$. The Cholesky decomposition of the covariance matrix is used to convert the non-correlated iterations into regionally correlated iterations [11]. The Pearson correlation values between regions are represented. ${ }^{5}$

\subsection{Model Structure}

An individual region has ten sectors and five production factors. (Table 1). Each representative firm behaves as a perfectly competitive profit-maximizing firm, following the Leontief production functional form (Figure 1). Factors of production are aggregated to create a valueadded composite good using a constant elasticity of substitution (CES) production function (Figure 2). I assume an elasticity of substitution of 0.26 for the agricultural sectors (paddy rice, wheat, and other grains). ${ }^{6}$ Two types of factor mobility assumptions are made for different scenarios: 1) all the factors are assumed to be mobile across sectors but not across international regions under full market adjustment and 2) unskilled labor alone is assumed to be mobile across sectors while the other factors are fixed to estimate short-run effects (explained in the following section). Factors of production are assumed to be fully employed.

Sectoral outputs produced by representative firms are distributed between foreign and domestic markets using a constant elasticity of transformation (CET) technology. The domestic goods and composite imports are synthesized

\footnotetext{
${ }^{5}$ The results are shown in Appendix, which is available upon request.

${ }^{6}$ See Table A2 for the elasticities of other sectors.
}

to make composite goods with a CES function [14]. Import composite goods are comprised of imported goods from various exporting regions, and composite exports are disaggregated into exports of individual regions.

Composite goods are consumed by households, government, investment agents, and other sectors as intermediate inputs. Food-related products aggregated for a food composite with a CES function and non-food products determine the utility of the representative household using the Cobb-Douglas form (Figure 2). Following estimates by past studies, the elasticity for household's food consumption is assumed to be $0.1 .^{7}$.

\subsection{Experimental Procedures}

I establish a two-stage simulation process to capture the benefits of the self-sufficiency policy for wheat in Egypt (Figure 3). It is assumed that unexpected events such as productivity shocks or an export quota hit the economy (short-term effects) after the full adjustment to a protectionist policy (long-term effects). The first-step simulation procedure looks for two intermediate equilibriums under the full factor mobility assumption: the ad valorem tariff rate to achieve wheat self-sufficiency and the optimal tariff for the maximized equivalent variation (EV) of households in Egypt. The second-step experiments include both stochastic and deterministic simulations to evaluate the impacts of yield volatility and export restrictions by Russia under the partial mobility assumption described above.

\footnotetext{
${ }^{7}$ The price elasticity of demand for wheat and maize is -0.12 and -0.24 , respectively [15].
} 


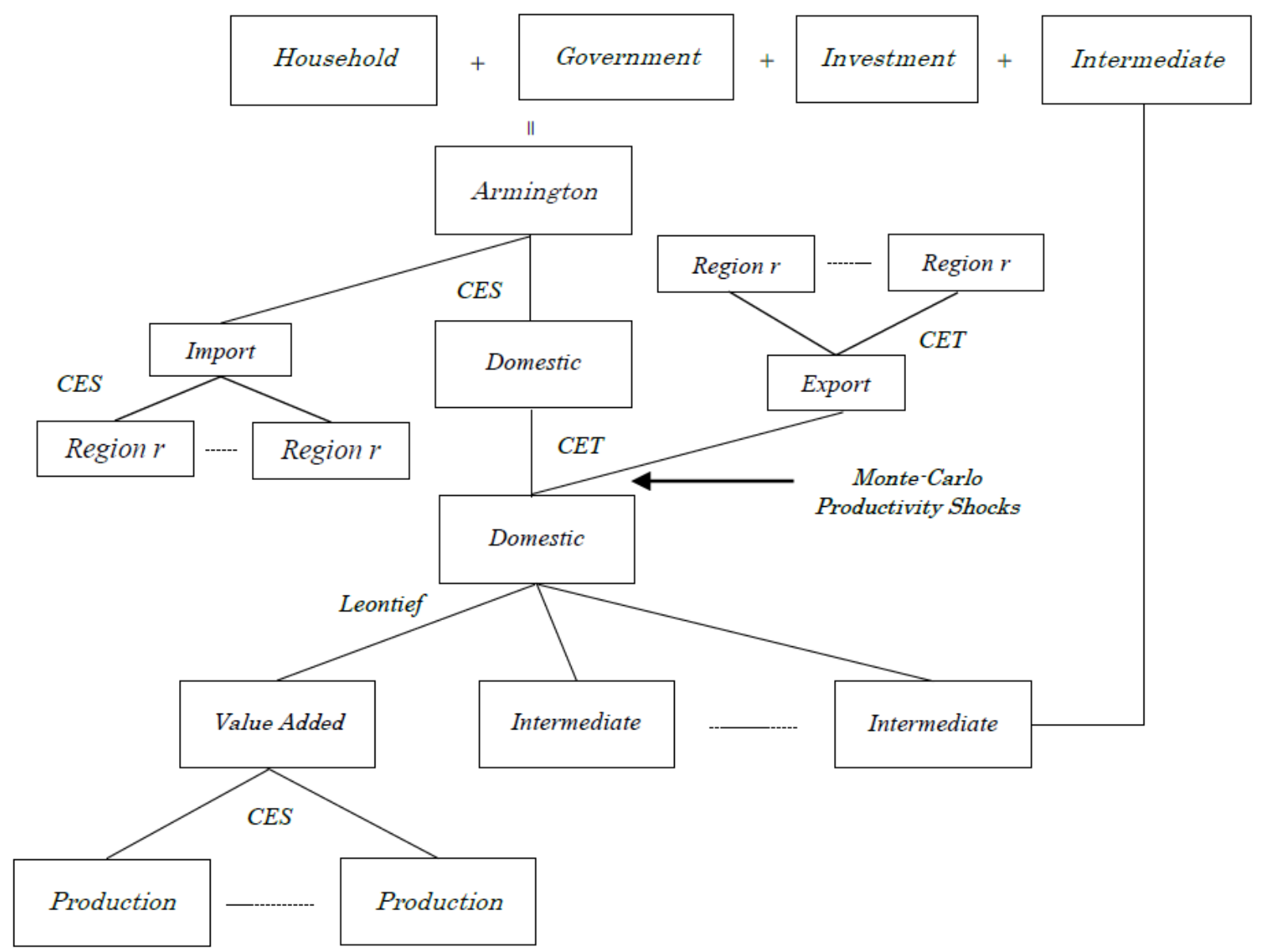

Figure 1. Overview of the model

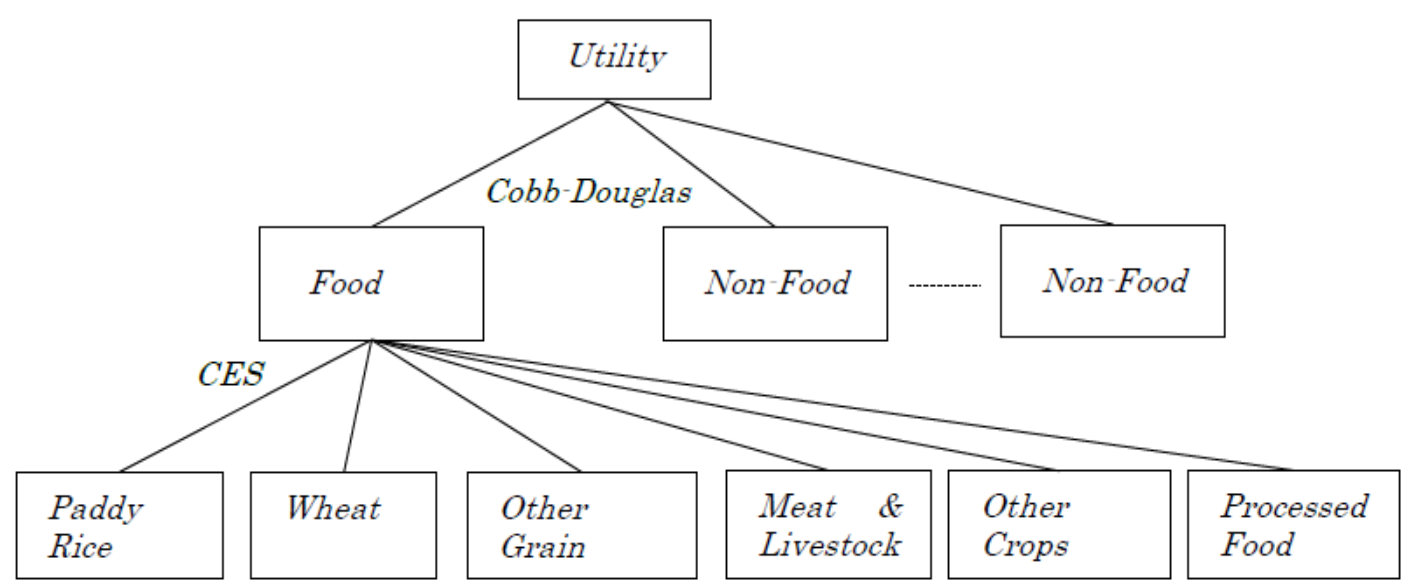

Figure 2. The structure of household consumption

\section{Reference equilibrium}

No shock
Intermediate equilibrium

Mobility: All factors

$\underline{\text { Shocks }}$

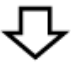

For

- Self-sufficiency $100 \%$

- Optimum tariff for EV
Final equilibrium

Mobility: Only unskilled labor

Shocks

- Stochastic productivity

- Russia's export ban

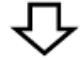

For

Time

- Distributed outcomes

- Deterministic

Figure 3. The simulation procedures 
Table 3. Scenarios and shocks

\begin{tabular}{|c|c|c|c|c|c|}
\hline & \multirow{2}{*}{\multicolumn{2}{|c|}{$\begin{array}{c}\text { Intermediate equilibrium } \\
\text { Tariff \& subsidy }\end{array}$}} & \multicolumn{3}{|c|}{ Final equilibrium } \\
\hline & & & \multicolumn{2}{|c|}{ Yield shock } & \multirow[b]{2}{*}{ Russia's export ban } \\
\hline & SSR $100 \%$ & Optimal & Egypt & Rest of the world & \\
\hline E-NO & & & $\mathrm{x}$ & & \\
\hline E-SS & $\mathrm{x}$ & & $\mathrm{x}$ & & \\
\hline E-OP & & $\mathrm{x}$ & $\mathrm{x}$ & & \\
\hline R-NO & & & & $\mathrm{x}$ & \\
\hline R-SS & $\mathrm{x}$ & & & $\mathrm{x}$ & \\
\hline R-OP & & $\mathrm{x}$ & & $\mathrm{x}$ & \\
\hline A-NO & & & $\mathrm{x}$ & $\mathrm{x}$ & \\
\hline A-SS & $\mathrm{x}$ & & $\mathrm{x}$ & $\mathrm{x}$ & \\
\hline A-OP & & $\mathrm{x}$ & $\mathrm{x}$ & $\mathrm{x}$ & \\
\hline $\mathrm{B}-\mathrm{NO}$ & & & & & $\mathrm{x}$ \\
\hline B-SS & $\mathrm{x}$ & & & & $\mathrm{x}$ \\
\hline
\end{tabular}

Notes: All the factors are mobile across sectors for intermediate equilibriums while unskilled labor alone is mobile for final equilibriums. SSR stands for self-sufficiency rate.

\subsection{Scenarios}

12 scenarios are set up to examine the resilience of food security in Egypt against internal and external shocks with three policy options: no policy, optimal tariff, and full self-sufficiency. As explained, two-step simulation procedures for intermediate and final equilibriums are made to quantify the impacts.

It is assumed that Egypt's government has three policy options: 1) it implements no food policy, 2) it raises its import tax rate on wheat and the revenue is spent on wheat production subsidies to optimize the duty rate for households' welfare, and 3) the identical food policy is implemented for full wheat self-sufficiency. These different policies are expressed as "NO", "SS", and "OP", respectively (Table 3).

Based on the three policy options, the country faces productivity shocks from domestic and foreign wheat sectors in the final equilibrium simulations from which I can identify the effectiveness of the different policies by comparing, for instance, Scenarios A-NO with A-SS. I form three scenario factors in the final equilibrium process: 1) wheat yield shocks only in Egypt, 2) shocks in rest of the world, and 3) Russia's export quota on wheat.

Scenarios A-NO, A-SS, and A-OP run realistic productivity simulations with shocks being given in all the countries. All regions but Egypt experience yield variability in Scenarios R0, R-SS, and R-OP. Scenarios E0, E-SS, and E-OP measure the effects of domestic productivity fluctuations of wheat. Under the three different regimes in Egypt, Russia's government restricts wheat exports to all regions of the world in Scenario B-NO, B-SS, and B-OP. ${ }^{8}$

\section{Results}

I simulate regionally correlated wheat yield shocks and an export ban on wheat by Russia and quantify potential benefits and costs of a self-sufficiency program in Egypt.

\footnotetext{
${ }^{8}$ Wheat export is reduced by $95 \%$ in Scenarios B0, B1 and B2 to avoid computational difficulties.
}

\subsection{Simulations for Intermediate Equilibriums}

The import duty on wheat increases by one-percent to search for the tax rate to achieve self-sufficiency in wheat and the optimal tax rate in the simulations. I find that Egypt becomes self-sufficient and optimal to household welfare with a $24 \%$ and $10 \%$ tariff increase, which brings about \$19 million and \$105 million as a positive welfare effect, respectively. Although an additional import tax is usually supposed to make a negative welfare effect due to a rise in consumer prices, the protective policy benefits agricultural producers by increasing their income with higher domestic price of wheat.

\subsection{Yield Shocks in Egypt}

With Egypt relying more on domestic supply sources, the volatility of household welfare in Scenarios E-SS and E-OP is greater than that in Scenario E-NO, which, accordingly, leads to higher fluctuations in the domestic price (Table 4). The worst case in 500 experiments with the self-sufficiency policy leads to a decline in household welfare by $19 \%$ compared with the no-policy scenario. By the same token, the higher tariff measure affects the highest price level. As the dependency on domestic supply in Scenario E-SS is higher than that in Scenario E-NO, the volatility of both EV and price becomes greater under the self-sufficiency regime.

\subsection{Yield Shocks in the Rest of the World}

Scenarios R-NO, R-SS, and R-OP enable us to test whether or not the new food system of Egypt can enhance the resilience against external productivity shocks. The full self-sufficiency policy plays a significant role in protecting household welfare from foreign yield variations, reducing the volatility by $39 \%$ and $23 \%$ in Scenarios E-SS and E-OP, respectively. It also hugely contributes to the alleviation of the greatest negative welfare shock with the reform, which curtails $44 \%$ and $29 \%$ of the bottom cases compared to the welfare with no policy. Hiking import tariffs also works, but limitedly, to relieve price volatility and to dampen the highest price by approximately $8 \%$. 
Table 4. Summary of the simulation results

\begin{tabular}{|c|c|c|c|c|c|c|c|c|c|}
\hline & \multicolumn{4}{|c|}{ Welfare (EV) [mil. US\$] } & \multicolumn{4}{|c|}{ Domestic wheat price [\%] } & \multirow{2}{*}{$\begin{array}{c}\text { SSR } \\
1=100 \%\end{array}$} \\
\hline & Min & Mean & $\operatorname{Max}$ & $\mathrm{SD}^{*}$ & Min & Mean & Max & $\mathrm{SD}^{*}$ & \\
\hline E-NO & -789.5 & -14.8 & 714.5 & 231.7 & -6.0 & 0.1 & 6.5 & 1.9 & 0.60 \\
\hline E-SS & -938.6 & -0.6 & 845.3 & 274.8 & -7.7 & 2.8 & 13.6 & 3.2 & 1.00 \\
\hline E-OP & -784.3 & 88.4 & 893.6 & 258.5 & -7.9 & 0.3 & 8.6 & 2.5 & 0.81 \\
\hline R-NO & -3331.6 & -133.6 & 1318.2 & 711.5 & -23.6 & 2.9 & 69.5 & 13.8 & 0.60 \\
\hline R-SS & -1850.4 & -53.4 & 878.1 & 432.4 & -19.3 & 5.2 & 64.1 & 12.3 & 1.00 \\
\hline $\mathrm{R}-\mathrm{OP}$ & -2360.4 & 8.5 & 1156.1 & 547.3 & -22.4 & 2.8 & 64.8 & 13.0 & 0.82 \\
\hline A-NO & -4050.9 & -173.3 & 1813.1 & 897.4 & -27.6 & 3.2 & 76.5 & 15.3 & 0.60 \\
\hline A-SS & -2665.9 & -100.1 & 1475.4 & 665.9 & -26.1 & 5.8 & 75.7 & 14.9 & 1.00 \\
\hline A-OP & -3148.5 & -35.9 & 1711.4 & 761.5 & -27.7 & 3.3 & 73.9 & 15.1 & 0.82 \\
\hline
\end{tabular}

Notes: * indicates that the SD is estimated based on the intermediate equilibriums. SSR stands for self-sufficiency rate.

It is important to compare the figures of SD between the scenarios, where shocks occur only in Egypt and those where shocks are given in the rest of the world, in order to understand the location that most influences Egypt's household welfare. The SDs of the foreign-shock scenarios (R-NO, R-SS, and R-OP) are two or three times larger than those in domestic shock scenarios (E-NO, E-SS, and E-OP), implying that productivity variability outside Egypt could more crucially affect the living standards of the nation.

\subsection{Yield Shocks all over the World}

With productivity changes occurring globally in the model, I can assess the stability of the socioeconomic structure against the synthesized shocks of domestic and foreign markets. Again, the agricultural policy measure stabilizes people's welfare in Egypt, diminishing its fluctuation by $26 \%$ in Scenario A-SS in comparison to that in Scenario A-NO. Egypt encounters the worst situation, suffering \$2,666 million even with 100\% self-sufficiency (Scenario A-SS), which, however, is abated by $34 \%$ compared with the scenario with no policy (Scenario A-NO).

While the experiments reveal the powerful effectiveness in stabilizing $\mathrm{EV}$, the ability to lower price volatility is smaller with $11 \%$ and $6 \%$ alleviations in Scenarios A-SS and A-OP, respectively. Likewise, the highest price spike is likely to be reduced by $8 \%$ under the full self-sufficiency policy.

The similarity of the SD values between the scenario group with global productivity shocks and that with shocks in the rest of the world suggest that a yield shock from abroad is a more influential factor than that from Egypt. Yet, the proximity between ex-ante and ex-post values varies and gets closer, which suggests that the international price transmission from overseas wanes due to the encouraged production in the state.

\subsection{Geographic Locations to Influence Egypt's Economy}

Table 5 displays to what extent changes in wheat yield in each region influence household welfare and wheat prices in Egypt by calculating the Pearson correlation from those variables. Russia is the foreign supplier that most affects Egypt's welfare, which is positively correlated to almost the same degree as the yield in Egypt. Notwithstanding, the gap of correlations between the two countries widens under self-sufficiency schemes (Scenarios A-SS and A-OP) although Kazakhstan's is different with its correlation increasing after the measure.

By the same token, Russia plays an important role in the correlation relationship with wheat price movement in Egypt, which changes the price as much as productivity in Egypt. The food self-sufficiency program also has effects in shielding the price in Egypt from yield variability of trade partners, though Kazakhstan is more strongly linked with the price in Egypt with the policy implementation.

\subsection{Export Ban by Russia}

In 2010, Russia banned its export of wheat after millions of acres withered due to a severe drought that drove up the global price and sparked food riots in Egypt. This section discusses how effective the autarky policy is against such an uncertain political decision. An export ban on wheat with partial factor mobility (unskilled labor only is mobile) is assumed to gauge short-run effects (Scenarios B-NO, B-SS, and B-OP) after the implementation of the tax reform in which factors are fully mobile across sectors for long-run effects (Scenarios M-SS and M-OP).

Egypt's households experience a \$1,433 million negative effect from the export restriction under the current tax scheme while they lose \$740 million and \$919 million after raising the import duty rate in Scenarios B-SS and B-OP, which reveals substantial benefits to enhance its food security, mitigating the damage by $48 \%$ and $36 \%$, respectively (Table 6). The interpretation of the benefits depends on how frequently such an export restriction is imposed. If it occurs once every two years, the gains are divided by two, namely $\$ 346.4$ million and \$256.75 million in Scenarios B-SS and B-OP, respectively.

Another point of view is that Russia is also considerably hurt by imposing the export quota, which causes a rise in the international wheat price and Egypt to import from other regions such as the U.S. and France. These dual variations profit other exporters, and, in contrast, put additional losses on importers such as the EU, Sub-Saharan Africa, and the MENA with higher procurement cost (Scenario B-NO). After the tax reform, the curtailed demand for wheat in the global market owing to the reduction of imports by Egypt worsens the welfare of exporters and improves that of other importers with moderate price rises (Scenarios B-SS and B-OP). These changes appear in the beneficial effects (the first and second columns from the right in Table 6). 
Table 5. Correlations between EV vs TFP and wheat price vs TFP

\begin{tabular}{|c|c|c|c|c|c|c|}
\hline & & & & & & \\
\hline & & $\mathrm{s} E V \mathrm{v}$ & & & wheat & \\
\hline & A-NO & A-SS & A-OP & A-NO & A-SS & $\mathrm{A}-\mathrm{OP}$ \\
\hline Egypt & 0.76 & 0.84 & 0.80 & -0.68 & -0.74 & -0.71 \\
\hline Russia & 0.64 & 0.60 & 0.62 & -0.65 & -0.64 & -0.64 \\
\hline USA & 0.34 & 0.35 & 0.34 & -0.33 & -0.33 & -0.33 \\
\hline France & 0.29 & 0.25 & 0.27 & -0.31 & -0.30 & -0.31 \\
\hline Ukraine & 0.38 & 0.33 & 0.35 & -0.41 & -0.39 & -0.40 \\
\hline Kazakhstan & 0.39 & 0.44 & 0.41 & -0.34 & -0.37 & -0.35 \\
\hline Australia & 0.16 & 0.17 & 0.16 & -0.15 & -0.15 & -0.15 \\
\hline Romania & 0.29 & 0.26 & 0.27 & -0.32 & -0.30 & -0.31 \\
\hline Poland & 0.46 & 0.45 & 0.46 & -0.46 & -0.46 & -0.46 \\
\hline EU & 0.68 & 0.63 & 0.66 & -0.71 & -0.69 & -0.70 \\
\hline MENA & 0.66 & 0.66 & 0.66 & -0.65 & -0.66 & -0.66 \\
\hline SSA & 0.52 & 0.52 & 0.52 & -0.51 & -0.51 & -0.51 \\
\hline ROW & 0.56 & 0.55 & 0.55 & -0.56 & -0.57 & -0.57 \\
\hline
\end{tabular}

Table 6. Effects of Russia's export ban on welfare in Egypt

\begin{tabular}{|c|c|c|c|c|c|}
\hline & \multicolumn{3}{|c|}{ Welfare impact (EV) [US\$] } & \multicolumn{2}{|c|}{ Potential benefit [US\$] } \\
\hline & (1) B-NO & (2) B-SS & (3) B-OP & $(2)-(1)$ & $(3)-(1)$ \\
\hline Egypt & -1432.5 & -739.7 & -919.0 & 692.8 & 513.5 \\
\hline Russia & -1375.4 & -1102.6 & -1218.7 & 272.8 & 156.7 \\
\hline USA & 1175.2 & 702.8 & 898.3 & -472.4 & -276.9 \\
\hline France & 894.4 & 586.8 & 714.1 & -307.6 & -180.3 \\
\hline Ukraine & 102.0 & 60.3 & 77.8 & -41.7 & -24.2 \\
\hline Kazakhstan & 161.7 & 125.3 & 140.9 & -36.4 & -20.8 \\
\hline Australia & 883.6 & 648.4 & 748.3 & -235.2 & -135.3 \\
\hline Romania & 36.3 & 11.8 & 22.0 & -24.5 & -14.3 \\
\hline Poland & -50.0 & -44.2 & -46.9 & 5.8 & 3.1 \\
\hline EU & -1395.2 & -1140.1 & -1251.5 & 255.1 & 143.8 \\
\hline MENA & -590.6 & -542.1 & -556.2 & 48.5 & 34.4 \\
\hline SSA & -679.0 & -553.4 & -604.5 & 125.6 & 74.5 \\
\hline ROW & -2041.1 & -1514.5 & -1745.2 & 526.6 & 295.9 \\
\hline
\end{tabular}

If policy makers focus on and enhance the resilience of the economy against such uncertain supply shocks in policy planning, the frequency of occurrence of events needs to be considered to estimate the potential gain from the deterministic experiments. Taking into account the rightward trend of politics in recent years, the likelihood of world countries restricting exports could grow exponentially, which suggests greater policy gains could be estimated even stochastically.

\subsection{Robustness Tests for Uncertain Parameters $^{9}$}

A CGE model encompasses a number of assumptions of which elasticity parameter values could largely influence the results in particular. Though the elasticities used in the model have been econometrically estimated, those outcomes vary depending on the literature. I conduct sensitivity analyses for the primary results regarding the Armington elasticity that governs international trade and the elasticity for value-added composite goods that represent the substitution between the factors of production. As a result, it is found that the primal results

\footnotetext{
9 The sensitivity simulation results are summarized in the Appendix,
} which is available upon request. shown above are robust against the assumptions of the parameters.

In Scenario A-OP, the S.D. (volatility) of household welfare is reduced by $29 \%$ and $22 \%$ with $+30 \%$ and $-30 \%$ changes in the Armington elasticity for wheat sector, respectively while it is abated by $26 \%$ in the main analysis. The variable ranges between $22 \%$ and $30 \%$ when the elasticity of value-added is altered by $\pm 30 \%$. The beneficial effects of the autarky policy (Scenario B-SS) to an export restriction by Russia are estimated at $\$ 624$ million and $\$ 817$ million with $+30 \%$ and $-30 \%$ changes in the Armington elasticity and $\$ 600$ million and $\$ 858$ million with the value-added elasticity being varied by $+30 \%$ and $-30 \%$, respectively. In spite of that these results differ under the various settings of the parameters, they consistently indicate solid positive effects.

\section{Discussions and Conclusions}

I conducted both stochastic and deterministic simulations to show the effects of a self-sufficiency policy for Egypt on food security using a multi-regional stochastic CGE model. The simulations show that Egypt becomes self-sufficient in wheat with a $24 \%$ increase in the import tariff, and the welfare of households reaches the optimum tariff at $10 \%$ receiving $\$ 105$ million. 
Expectedly, the welfare volatility is enlarged by domestic productivity changes after the policy implementation, increasing the dependency on domestic supply sources while the economy becomes more resistant to external yield shocks. When considering productivity variability all over the world, welfare volatility stabilizes by $23 \%$, and the worst welfare consequence is ameliorated by $34 \%$.

Egypt experiences a huge negative welfare effect of $\$ 1,432$ million with a wheat embargo by Russia with the status quo, which, however, is halved by the selfsufficiency policy. Russia also incurs a considerable welfare burden by the restriction while other exporters are benefitted due to higher wheat price in the global market. Notwithstanding, Egypt cuts import demand under the self-sufficiency scheme, restrains the sharp international price rise of wheat, and improves the welfare of other importing regions such as the EU, the MENA, and SubSaharan Africa.

Limitations of the analysis are worth mentioning. The feasibility of the measure was not debated in this paper, assuming that farming operators are able to expand farmland space for wheat production, incentivized by the subsidy. About $95 \%$ of the population lives along the Nile delta where farmland is particularly fertile, but arable space in those areas, however, has been reduced due to urbanization and desertification despite the considerable efforts, but little success, made by the government to reclaim arid land for farmland [16]. Another potential impediment to reach autarky is on water availability. Egypt already faces a remarkable water deficit using 55.5 billion cubic meters of water per year from the Nile, which is the only source of water [16]. Doubling wheat production to meet the demand simply means that the nation needs double the amount of water.

In this article, counter-factual simulations using a quantitative model has been conducted to deduce the benefits of food autarky system, but various approaches need to be adopted to glean additional evidence with respect to the theme. Statistical or econometrical analysis would be an effective option to characterize the heterogeneity from historical data. South Korea, for instance, encountered a drastic reform of domestic agricultural markets through the Uruguay Round of the WTO, which led the nation to being heavily dependent on foreign supply [17]. Such similar cases exist in a variety of jurisdictions around the world, and should be examined by quantitative tools to corroborate the findings obtained in this research.

\section{Statement of Competing Interests}

The author has no competing interests.

\section{References}

[1] Clapp, J., 2017. Food self-sufficiency: Making sense of it, and when it makes sense. Food Policy Vol. 66 pp.83-96.

[2] Tanaka, T., Hosoe, N., 2011. Does agricultural trade liberalization increase risks of supply-side uncertainty?: Effects of productivity shocks and export restrictions on welfare and food supply in Japan. Food Policy 36 pp.368-377.

[3] TRADING ECONOMICS, Available at https://tradingeconomics.com/egypt/government-debt-to-gdp (accessed 10.1.2018)

[4] McGill, J., Prikhodko, D., Sterk, B., Talks, P., 2015. Egypt Wheat sector review. FAO Investment Centre. Available at http://www.fao.org/3/a-i4898e.pdf (accessed 10.1.2018).

[5] Sadoulet, E., Janvry A., 1992. Agricultural trade liberalization and low income countries: A general equilibrium-multimarket approach. American Journal of Agricultural Economics Vol74(2): 268-280.

[6] Cramer, G.L., Wailes, E.J., Shui, S., 1993. Impacts of liberalizing trade in the world rice market. American Journal of Agricultural Economics Vol. 75(1), 219-226.

[7] Warr, P., Food Security vs. Food Self-sufficiency: The Indonesian Case. Crawford School Research Paper No. 2011/04. Available at https://papers.ssrn.com/sol3/papers.cfm?abstract_id=1910356 (accessed 10.1.2018).

[8] Bishwajit, G., 2014. Food security and food self-sufficiency in China: from past to 2050. Food and Energy Security 3(2): pp. 86-95.

[9] Bishwajit, G., Sarker, S., Kpoghomou, M., Gao, H., Jun, L., Yin, D., 2013. Self-sufficiency in rice and food security: a South Asian perspective. Agriculture \& Food Security Vol 2 (10).

[10] Clarete, R. L., Adriano, L., Esteban, A., 2013. Rice Trade and Price Volatility: Implications on ASEAN and Global Food Security. ADB Economic Working Paper Series No. 368. Available at <https://www.adb.org/sites/default/files/publication/30390/ewp368.pdf $>$ (accessed 10.1.2018).

[11] Devarajan, S., Lewis, J.D., Robinson, S., 1990. Policy lessons from trade-focused, two sector models. Journal of Policy Modelling 12 (4), 625-657.

[12] Ünal, G.E., Karapinar, B., Tanaka, T., 2017. Welfare-at-Risk and Extreme Dependency of Regional Wheat Yields: Implications of a Stochastic CGE Model. Journal of Agricultural Economics, forthcoming.

[13] Valenzuela, E., Hertel, T.W., Keeney, R., Remimer, J., 2007. Assessing Global Computable General Equilibrium Model Validity Using Agricultural Price Volatility. American Journal of Agricultural Economics 89(2): 383-397.

[14] Armington, P.S., 1969. A theory of demand for products distinguished by place of production. International Monetary Fund Staff Paper 16(1), 159-178.

[15] Fayaad, Basem S.; Johnson, Stanley R.; and El-Khishin, Mohamed, "Consumer Demand for Major Foods in Egypt" (1995). CARD Working Papers. 214. Available at http://lib.dr.iastate.edu/card_workingpapers/214 (accessed 10.1.2018)

[16] Megahid, Ahmed, 2016. Egypt's chasing impossible dream of wheat sufficiency. The Arab Weekly $5^{\text {th }}$ June. Available at http://www.thearabweekly.com/Economy/5359/Egypt\%E2\%80\%9 9s-chasing-impossible-dream-of-wheat-sufficiency(accessed 10.1.2018).

[17] Hong, S., and Cheng, F., 2007. Trade Liberalization in South Korea's Rice Sector: Some Policy Implications. Case Study \#10-6 of the Program: Food Policy for Developing Countries: The role of Government in the Global Food System. 


\section{Appendix}

Table A1. Regional yield correlation matrix

\begin{tabular}{|c|c|c|c|c|c|c|c|c|c|c|c|c|c|}
\hline & Egypt & Russia & France & USA & Ukraine & Kazakhstan & Australia & Romania & Poland & $\mathrm{EU}$ & MENA & SSA & ROW \\
\hline Egypt & 1.00 & & & & & & & & & & & & \\
\hline Russia & 0.37 & 1.00 & & & & & & & & & & & \\
\hline France & 0.15 & 0.11 & 1.00 & & & & & & & & & & \\
\hline USA & 0.27 & -0.04 & -0.27 & 1.00 & & & & & & & & & \\
\hline Ukraine & 0.11 & 0.55 & 0.27 & -0.27 & 1.00 & & & & & & & & \\
\hline Kazakhstan & 0.55 & 0.50 & -0.24 & 0.04 & 0.03 & 1.00 & & & & & & & \\
\hline Australia & 0.20 & -0.16 & 0.00 & 0.34 & -0.02 & -0.22 & 1.00 & & & & & & \\
\hline Romania & 0.10 & 0.20 & 0.11 & -0.01 & 0.70 & -0.01 & 0.37 & 1.00 & & & & & \\
\hline Poland & 0.35 & 0.45 & 0.39 & 0.09 & 0.65 & 0.07 & 0.06 & 0.32 & 1.00 & & & & \\
\hline EU & 0.35 & 0.81 & 0.36 & 0.10 & 0.72 & 0.20 & 0.01 & 0.46 & 0.66 & 1.00 & & & \\
\hline MENA & 0.51 & 0.33 & 0.18 & 0.11 & 0.21 & 0.16 & -0.10 & 0.07 & 0.12 & 0.32 & 1.00 & & \\
\hline SSA & 0.43 & 0.19 & 0.19 & 0.50 & -0.02 & 0.06 & 0.00 & -0.11 & 0.36 & 0.19 & 0.41 & 1.00 & \\
\hline ROW & 0.40 & 0.08 & 0.19 & 0.25 & -0.07 & 0.19 & -0.11 & 0.00 & 0.03 & 0.11 & 0.45 & 0.44 & 1.00 \\
\hline
\end{tabular}

Table A2. Wheat yield volatility estimated by ARMA model

\begin{tabular}{lcccc}
\hline & \multicolumn{4}{c}{ Residuals of ARMA of yields (1995-2014) } \\
\cline { 2 - 4 } & Min & Mean & Max & SD \\
\hline Egypt & -0.123 & -0.003 & 0.099 & 0.049 \\
Russia & -0.228 & 0.022 & 0.201 & 0.122 \\
France & -0.131 & -0.001 & 0.098 & 0.072 \\
USA & -0.138 & 0.003 & 0.144 & 0.068 \\
Ukraine & -0.379 & 0.008 & 0.330 & 0.171 \\
Kazakhstan & -0.235 & 0.010 & 0.342 & 0.153 \\
Australia & -0.419 & 0.000 & 0.205 & 0.182 \\
Romania & -0.301 & 0.003 & 0.081 \\
Poland & -0.166 & 0.012 & 0.182 & 0.075 \\
EU & -0.122 & 0.015 & 0.174 & 0.077 \\
MENA & -0.139 & 0.005 & 0.140 & 0.131 \\
SSA & -0.426 & 0.021 & 0.166 & 0.040 \\
ROW & -0.103 & 0.002 & 0.055 & \\
\hline
\end{tabular}

Table A3. Elasticity parameters in the model

\begin{tabular}{lll}
\hline Sector & Value-added & Armington \\
\hline Paddy rice & 0.26 & 5.05 \\
Wheat & 0.26 & 4.45 \\
Other cereals & 0.26 & 1.30 \\
Crops & 0.30 & 2.33 \\
Meat \& livestocks & 0.52 & 3.11 \\
Processed foods & 1.12 & 2.15 \\
Extraction & 0.20 & 4.91 \\
Manufacturing & 1.26 & 3.40 \\
Services & 1.34 & 1.94 \\
Transport & 1.68 & 1.90 \\
\hline
\end{tabular}

Table A4. Sensitivity analysis with changes in the Armington elasticity $+30 \%$

\begin{tabular}{|c|c|c|c|c|c|c|c|}
\hline & \multicolumn{4}{|c|}{ Welfare (EV) [US\$] } & \multicolumn{2}{|c|}{ Domestic price [\%] } & \multirow{2}{*}{$\begin{array}{c}\text { SSR } \\
{[1.0=100 \%]}\end{array}$} \\
\hline & Min & Mean & Max & $\mathrm{SD}^{*}$ & Mean & $\mathrm{SD}^{*}$ & \\
\hline E-NO & -764.5 & $\begin{array}{ll}-13.8 \\
\end{array}$ & 707.9 & 227.1 & 0.10 & 1.65 & 0.60 \\
\hline E-SS & -998.6 & -18.8 & 876.8 & 289.3 & 3.51 & 3.12 & 1.06 \\
\hline E-OP & -806.6 & 85.8 & 923.8 & 267.0 & 0.56 & 2.36 & 0.85 \\
\hline R-NO & -3248.4 & -128.9 & 1275.4 & 700.0 & 2.82 & 13.77 & 0.60 \\
\hline R-SS & -1568.5 & -57.7 & 754.5 & 376.8 & 5.79 & 12.02 & 1.06 \\
\hline R-OP & -2122.2 & 16.9 & 1066.0 & 504.5 & 3.04 & 12.88 & 0.86 \\
\hline A-NO & -3953.2 & -167.5 & 1779.0 & 883.0 & 3.13 & 15.08 & 0.60 \\
\hline A-SS & -2419.0 & -106.4 & 1398.0 & 628.0 & 6.41 & 14.60 & 1.06 \\
\hline $\mathrm{A}-\mathrm{OP}$ & -2931.8 & -28.6 & 1655.3 & 728.9 & 3.49 & 14.79 & 0.85 \\
\hline
\end{tabular}


Table A5. Sensitivity analysis with changes in the Armington elasticity $\mathbf{- 3 0 \%}$

\begin{tabular}{|c|c|c|c|c|c|c|c|}
\hline & \multicolumn{4}{|c|}{ Welfare (EV) [US\$] } & \multicolumn{2}{|c|}{ Domestic price [\%] } & \multirow{2}{*}{$\frac{\text { SSR }}{[1.0=100 \%]}$} \\
\hline & Min & Mean & Max & $\mathrm{SD}^{*}$ & Mean & SD* & \\
\hline E-NO & -830.1 & -16.7 & 723.4 & 238.9 & 0.16 & 2.38 & 0.60 \\
\hline E-SS & -863.1 & 30.0 & 816.8 & 258.2 & 1.87 & 3.33 & 0.92 \\
\hline E-OP & -765.8 & 93.2 & 862.8 & 250.4 & -0.10 & 2.84 & 0.77 \\
\hline R-NO & -3478.0 & -143.5 & 1396.2 & 732.3 & 2.98 & 13.85 & 0.60 \\
\hline R-SS & -2243.4 & -43.6 & 1066.1 & 508.4 & 4.35 & 12.65 & 0.93 \\
\hline $\mathrm{R}-\mathrm{OP}$ & -2692.9 & -3.4 & 1293.9 & 605.5 & 2.53 & 13.24 & 0.77 \\
\hline A-NO & -4219.9 & -184.9 & 1863.2 & 922.5 & 3.43 & 15.73 & 0.60 \\
\hline A-SS & -3018.1 & -88.1 & 1591.6 & 721.7 & 5.01 & 15.35 & 0.93 \\
\hline A-OP & -3460.7 & -47.0 & 1792.7 & 809.0 & 3.07 & 15.52 & 0.77 \\
\hline
\end{tabular}

Table A6. Sensitivity analysis with a change in the elasticity of the value added by $+30 \%$

\begin{tabular}{|c|c|c|c|c|c|c|c|}
\hline & \multicolumn{4}{|c|}{ Welfare (EV) [US\$] } & \multicolumn{2}{|c|}{ Domestic price [\%] } & \multirow{2}{*}{$\begin{array}{c}\text { SSR } \\
1.0=100 \%]\end{array}$} \\
\hline & Min & Mean & $\operatorname{Max}$ & SD* & Mean & SD* & \\
\hline E-NO & -783.4 & -14.6 & 713.2 & 230.7 & 0.12 & 1.94 & 0.60 \\
\hline E-SS & -928.5 & 0.1 & 841.9 & 272.8 & 2.77 & 3.14 & 1.00 \\
\hline E-OP & -773.8 & 89.0 & 889.0 & 256.3 & 0.25 & 2.52 & 0.81 \\
\hline R-NO & -2450.3 & -89.0 & 1247.3 & 592.7 & 1.91 & 11.24 & 0.60 \\
\hline R-SS & -1410.3 & -29.4 & 848.7 & 372.1 & 4.25 & 9.90 & 1.00 \\
\hline R-OP & -1737.3 & 41.1 & 1108.8 & 462.5 & 1.87 & 10.56 & 0.82 \\
\hline A-NO & -3079.2 & -124.2 & 1739.0 & 772.9 & 2.23 & 12.69 & 0.60 \\
\hline A-SS & -2128.7 & -71.0 & 1446.6 & 599.3 & 4.78 & 12.36 & 1.00 \\
\hline A-OP & -2427.1 & 1.7 & 1662.1 & 670.0 & 2.28 & 12.49 & 0.82 \\
\hline
\end{tabular}

Table A7. Sensitivity analysis with a change in the elasticity of the value added by $\mathbf{- 3 0 \%}$

\begin{tabular}{|c|c|c|c|c|c|c|c|}
\hline & \multicolumn{4}{|c|}{ Welfare (EV) [US\$] } & \multicolumn{2}{|c|}{ Domestic price [\%] } & \multirow{2}{*}{$\begin{array}{c}\text { SSR } \\
{[1.0=100 \%]}\end{array}$} \\
\hline & Min & Mean & Max & SD* & Mean & SD* & \\
\hline E-NO & -800.9 & -15.3 & 719.2 & 234.1 & 0.12 & 1.94 & 0.60 \\
\hline E-SS & -954.2 & -1.5 & 851.1 & 277.9 & 2.84 & 3.26 & 1.00 \\
\hline E-OP & -800.7 & 87.7 & 901.3 & 262.1 & 0.28 & 2.58 & 0.81 \\
\hline R-NO & -5452.9 & -234.1 & 1422.7 & 967.3 & 5.04 & 19.44 & 0.60 \\
\hline R-SS & -2907.2 & -106.9 & 923.8 & 563.0 & 7.22 & 17.46 & 1.01 \\
\hline R-OP & -3862.7 & -64.7 & 1227.6 & 730.8 & 4.87 & 18.43 & 0.82 \\
\hline A-NO & -6396.7 & -283.6 & 1917.7 & 1168.7 & 5.53 & 21.20 & 0.60 \\
\hline A-SS & -3958.5 & -164.1 & 1516.1 & 812.0 & 8.05 & 20.44 & 1.00 \\
\hline A-OP & -4890.0 & -119.7 & 1781.0 & 961.4 & 5.52 & 20.78 & 0.82 \\
\hline
\end{tabular}

Table A8. Sensitivity result of Russia's export ban with a change in the elasticity of the Armington elasticity by $+30 \%$

\begin{tabular}{|c|c|c|c|c|c|}
\hline & \multicolumn{3}{|c|}{ Welfare impact (EV) [US\$] } & \multicolumn{2}{|c|}{ Potential benefit [US\$] } \\
\hline & (1) B0 & (2) B-SS & (3) B-OP & $(2)-(1)$ & (3)-(1) \\
\hline Egypt & -1157.7 & -533.1 & -665.9 & 624.6 & 491.8 \\
\hline Russia & -1347.9 & -1035.7 & -1164.7 & 312.3 & 183.2 \\
\hline USA & 992.3 & 543.7 & 721.6 & -448.6 & -270.7 \\
\hline France & 810.9 & 508.5 & 628.8 & -302.3 & -182.1 \\
\hline Ukraine & 91.0 & 50.5 & 66.8 & -40.4 & -24.2 \\
\hline Kazakhstan & 162.1 & 122.8 & 139.1 & -39.3 & -22.9 \\
\hline Australia & 841.5 & 599.8 & 699.2 & -241.7 & -142.3 \\
\hline Romania & 28.7 & 6.8 & 15.5 & -21.9 & -13.1 \\
\hline Poland & -52.1 & -45.0 & -48.2 & 7.0 & 3.8 \\
\hline EU & -1385.5 & -1105.4 & -1224.2 & 280.1 & 161.3 \\
\hline MENA & -405.3 & -378.4 & -382.0 & 26.9 & 23.3 \\
\hline SSA & -574.0 & -455.6 & -501.8 & 118.4 & 72.2 \\
\hline ROW & -1975.6 & -1402.9 & -1646.3 & 572.7 & 329.3 \\
\hline World & -3971.6 & -3124.0 & -3362.0 & 847.6 & 609.6 \\
\hline
\end{tabular}


Table A9: Sensitivity result of Russia's export ban with a change in the elasticity of the Armington elasticity by $-30 \%$

\begin{tabular}{|c|c|c|c|c|c|}
\hline & \multicolumn{3}{|c|}{ Welfare impact (EV) [US\$] } & \multicolumn{2}{|c|}{ Potential benefit [US\$] } \\
\hline & (1) B0 & (2) B-SS & (3) B-OP & $(2)-(1)$ & (3)-(1) \\
\hline Egypt & -2000.8 & -1184.2 & -1444.3 & 816.6 & 556.5 \\
\hline Russia & -1408.3 & -1193.6 & -1288.3 & 214.7 & 120.0 \\
\hline USA & 1541.3 & 1025.1 & 1250.4 & -516.2 & -290.9 \\
\hline France & 1058.3 & 739.2 & 877.9 & -319.2 & -180.4 \\
\hline Ukraine & 123.7 & 79.6 & 99.0 & -44.1 & -24.7 \\
\hline Kazakhstan & 162.2 & 129.7 & 144.2 & -32.5 & -18.0 \\
\hline Australia & 968.3 & 740.5 & 841.5 & -227.7 & -126.8 \\
\hline Romania & 51.6 & 22.9 & 35.5 & -28.7 & -16.1 \\
\hline Poland & -45.5 & -41.5 & -43.5 & 4.0 & 2.0 \\
\hline $\mathrm{EU}$ & -1412.4 & -1193.2 & -1292.5 & 219.2 & 119.9 \\
\hline MENA & -956.1 & -873.5 & -905.1 & 82.6 & 51.0 \\
\hline SSA & -887.8 & -750.1 & -809.4 & 137.7 & 78.4 \\
\hline ROW & -2170.3 & -1703.9 & -1916.3 & 466.4 & 254.0 \\
\hline World & -4976.0 & -4203.1 & -4450.9 & 772.9 & 525.1 \\
\hline
\end{tabular}

Table A10. Sensitivity result of Russia's export ban with changes in the elasticity of the value-added Armington elasticity by $+30 \%$

\begin{tabular}{|c|c|c|c|c|c|}
\hline & \multicolumn{3}{|c|}{ Welfare impact (EV) [US\$] } & \multicolumn{2}{|c|}{ Potential benefit [US\$] } \\
\hline & (1) B0 & (2) B-SS & (3) B-OP & $(2)-(1)$ & (3)-(1) \\
\hline Egypt & -1290.4 & -690.4 & -833.8 & 600.0 & 456.6 \\
\hline Russia & -1302.3 & -1038.9 & -1150.7 & 263.5 & 151.7 \\
\hline USA & 809.9 & 443.8 & 595.4 & -366.1 & -214.6 \\
\hline France & 680.8 & 436.8 & 537.9 & -244.1 & -143.0 \\
\hline Ukraine & 75.8 & 41.9 & 56.2 & -33.9 & -19.7 \\
\hline Kazakhstan & 147.5 & 115.4 & 129.3 & -32.1 & -18.2 \\
\hline Australia & 737.8 & 542.3 & 625.7 & -195.5 & -112.2 \\
\hline Romania & 28.5 & 7.1 & 16.0 & -21.4 & -12.4 \\
\hline Poland & -55.4 & -47.9 & -51.3 & 7.4 & 4.0 \\
\hline EU & -1327.8 & -1088.9 & -1193.3 & 239.0 & 134.6 \\
\hline MENA & -308.9 & -333.4 & -316.8 & -24.5 & -7.9 \\
\hline SSA & -489.7 & -412.9 & -443.5 & 76.7 & 46.2 \\
\hline ROW & -1865.9 & -1379.8 & -1592.9 & 486.1 & 273.1 \\
\hline World & -4160.0 & -3405.0 & -3621.8 & 755.0 & 538.2 \\
\hline
\end{tabular}

Table A11. Sensitivity result of Russia's export ban with change in the elasticity of the value-added Armington elasticity by $-\mathbf{3 0} \%$

\begin{tabular}{|c|c|c|c|c|c|}
\hline & \multicolumn{3}{|c|}{ Welfare impact (EV) [US\$] } & \multicolumn{2}{|c|}{ Potential benefit [US\$] } \\
\hline & (1) B0 & (2) B-SS & (3) B-OP & (2)-(1) & (3)-(1) \\
\hline Egypt & $\begin{array}{ll}-1691.7 \\
\end{array}$ & -833.5 & -1076.4 & 858.2 & 615.3 \\
\hline Russia & -1445.3 & -1167.1 & -1285.7 & 278.2 & 159.6 \\
\hline USA & 1862.4 & 1181.9 & 1462.8 & -680.5 & -399.6 \\
\hline France & 1294.6 & 863.9 & 1041.5 & -430.8 & -253.1 \\
\hline Ukraine & 151.7 & 94.6 & 118.3 & -57.1 & -33.3 \\
\hline Kazakhstan & 193.0 & 146.8 & 166.4 & -46.2 & -26.6 \\
\hline Australia & 1169.6 & 853.3 & 986.8 & -316.3 & -182.7 \\
\hline Romania & 50.6 & 20.3 & 32.8 & -30.3 & -17.8 \\
\hline Poland & -40.9 & -37.9 & -39.5 & 2.9 & 1.4 \\
\hline EU & -1539.8 & -1248.6 & -1375.3 & 291.2 & 164.5 \\
\hline MENA & -1101.8 & -915.6 & -987.3 & 186.2 & 114.5 \\
\hline SSA & -1033.9 & -812.5 & -903.6 & 221.4 & 130.3 \\
\hline ROW & -2388.2 & -1777.6 & -2044.3 & 610.6 & 343.9 \\
\hline World & -4519.7 & -3632.1 & -3903.4 & 887.7 & 616.3 \\
\hline
\end{tabular}

